Journal of Engineering and Applied Sciences 14 (5): 1532-1537, 2019

ISSN: 1816-949X

(C) Medwell Journals, 2019

\title{
Determination of Coefficient of Transmissibility for Crushed Rocks
}

\author{
Marwah Abdullah Shlash, Hayder Sami Mohammed and Taghreed A.Musa \\ Department of Structures and Water Resources, Faculty of Engineering, \\ University of Kufa, Najaf, Iraq
}

\begin{abstract}
Rockfill gabions considered one of important self-spillway hydraulic structures, used as water distributor, regulator and other purposes. An experimental investigation was carried out to note the effect of the change of longitudinal slope and the change of rockfill size on the velocity at downstream side of gabion, all tests carried out under through flow regime type, the monosized of rockfill were used $(-76,+64),(-64,+50)$ and $(-50,+37.5) \mathrm{mm}$ with three longitudinal slope $0,0.014$ and 0.028 . Wooden frame meshed-side gabion with constant dimensions, $220 \mathrm{~cm}$ length of the bottom side $150 \mathrm{~cm}$ length of upper side of gabion, $0.3 \mathrm{~m}$ width and $0.35 \mathrm{~m}$ height. The result showed that the effective of discharge increasing on the value of velocity of downstream by increasing of rockfill size for same longitudinal slope and the effect of discharge decreasing on the velocity at downstream by increasing the longitudinal slope for the same rockfill size, a dimensional analysis concept used and non-linear regression by using IBM SPSS 21 program, to develop an empirical formula to estimate the velocity at downstream.
\end{abstract}

$\underline{\text { Key words: Rockfill gabions, coefficient of transmissibility, crushed rocks, program, empirical formula, velocity }}$

\section{INTRODUCTION}

Rocks are formations that contain a different type of minerals that exist in nature and are an essential part of the structure of the Earth's crust. Thus, the rock has a distinctive characteristic that distinguishes it from another rock and makes it a stand-alone unit. Rock is the basic unit in the construction of the earth as for the metal is the basic component of the rock. The rocks differ from each other in terms of their constituent metal types and the relationship of these minerals to each other in one rock, the abundance of rocks and their ease of use gave continuity to their use, making them more economical with concrete materials.

One of the important uses of crushed rocks when used in formation of dams are self-running flow or are also called the (check dam) (Fig. 1) where the principle of work is basically raising the level of water in the upstream side when placed in channels to perform work similar to the work of regulations in principle and in such a case, some flow of water passes through the barrier depending on the permeability of rocks and at the same time is lift water to a higher level at the channel's upstream.

The rocks in these uses are either freely placed or placed in a metal buckle called a (gabion). Therefore, since, rocky hydraulic structures are built in regular rock sizes, mechanical analysis of the rocks is required using a number of standard sieves. Moreover, some physical properties of rocks are identified, Use these

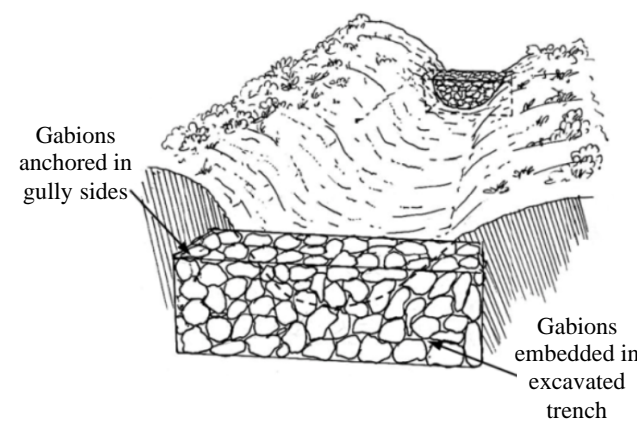

Fig. 1: Gabion check dam

rocks in regular sizes. There are many studies concerning hydraulic flow during and above rocks, especially, gravels.

Based on these studies, the current study investigated the transmissibility of the crushed rocks and its effect on the velocity after the gabion, during models of the broken rocks by placing them in a laboratory channel specified to hydraulic investigation.

Studies on flow in porous media: Most of the researchers interested in studying the flow during and above the aggregates, especially, the hydraulic properties used gravel in their tests and laboratory experiments. Darcy equation was adopted mainly in the study of flow through porous media when water velocity is low under laminar condition (Terzaghi et al., 1996) which represents the

Corresponding Author: Marwah Abdullah Shlash, Department of Structure and Water Resources, College of Engineering, University of Kufa, Al-Najaf, Iraq 
linear relationship between Velocity (V) and hydraulic gradient (i), $\mathrm{V}=\mathrm{K}^{*}$, where $(\mathrm{K})$ is transmissibility constant where Reynold's number ranges from $0.1-75$ for Laminar flow.

When Reynold's number exceeded the limits of the laminar flow, Parkin (1963) found that the relationship between velocity and hydraulic gradient was $\mathrm{V}=\mathrm{K}^{*} \mathrm{i}^{1 / 9}$ where $\mathrm{n}>1$ for aggregates.

By Al-Mohammed and Mohammed (2015), laboratory experiments, use flume with $10 \mathrm{~m}$ length, $0.3 \mathrm{~m}$ wide and $0.5 \mathrm{~m}$ depth investigate effectiveness of gravel size, length and height of gabion on upstream level, under two type of regime flow, through and transient, three different monosized gravel was used in gabion for each test, $(-14$, $+10),(-20,+14)$ and $(-25,+20)$, all gabion sample tested with horizontal slope, the result indicate for throughflow type, upstream level increase when the gravel size decrease for the same gabion length and for each gravel size, upstream level increases by increasing the gabion length. For transient flow regimes, the results showed the relation between upstream water level and discharge through gabion is linearly for through and transient flow regimes.

By Shekho (2009), laboratory experimentation, used of crushed rock instead of gravel to find the transmissibility constant with different graded two monosized $(-50.8,+38)$ and $(-25.4,+19.1) \mathrm{mm}$ and two other grades $\left(d_{50}\right), 33$ and $35 \mathrm{~mm}$, all the experiments perform on horizontal slope flume, all gabions samples dimension were $30 \mathrm{~cm}$ height, $10 \mathrm{~cm}$ width and $49 \mathrm{~cm}$ length, the result indicated that the transmissibility coefficient were between $(14.5-53) \mathrm{cm} / \mathrm{sec}$.

Izbash (1970) was found when studying flow through the porous media when increasing the Reynold's number over the critical limits, the velocity of flow through porous media, directly proportional to the square root of hydraulic gradient $(\mathrm{S}), \mathrm{V}=\mathrm{K}^{*} \mathrm{i}^{1 / 2}$.

Leps (1973) describe the relation between flow rate, legth of gabion and the heads in up and downstream for rectangular section by $3 \mathrm{Lq}^{2} / \mathrm{k}^{2}=\left(\mathrm{h}^{3}{ }_{1}-\mathrm{h}^{3}{ }_{2}\right)$.
Types of flow through rock porous media: There are five possible types of flow through gabion barrier can be observed (Maeno et al., 2002) as shown in Fig. 2 as follows:

Through flow (non-overflow): Happen when the water streams just pass through the permeable media.

Through flow limit (non-overflow): Is the condition of stream that the free surface vanishes from the upper edge of the porous barrier.

Transient flow: is the express that the stream gets into the filling material over the porous barrier.

Overflow limit: is the flow profile that the free surface reaches just the downstream edge of the gabion crest.

Laboratory experiment: All tests was performed in rectangular flume with a stainless steel bed and acrylic glass-sided walls to give obvious observation with $15 \mathrm{~m}$ long, $30 \mathrm{~cm}$ wide and $45 \mathrm{~cm}$ depth as shown in Fig. 3.

All experimental tests were fabricated in Hydraulics Laboratory of the Structures and Water Resources Department in the Faculty of Engineering of Al-Kufa University. Water was recycling inside the flume by used centrifugal pump with max. Flow rate $36 \mathrm{~L} / \mathrm{sec}$. Discharges magnitude measured by rectangular weir at the end of downstream flume. Three values of longitudinal slopes were taken $0,0.014$ and 0.028 . Three monosize crushed rocks samples were chosen had nominal dimeters $(-76$, $+64),(-64,+50)$ and $(-50,+37.5) \mathrm{mm}$.

The porosity of the three rockfill models were calculated by dividing the water volume that fill the voids of each samples by the size of the total model which can be expressed in the following equation:

$$
\mathrm{n}=\frac{\mathrm{V}_{\mathrm{v}}}{\mathrm{V}_{\mathrm{T}}}
$$

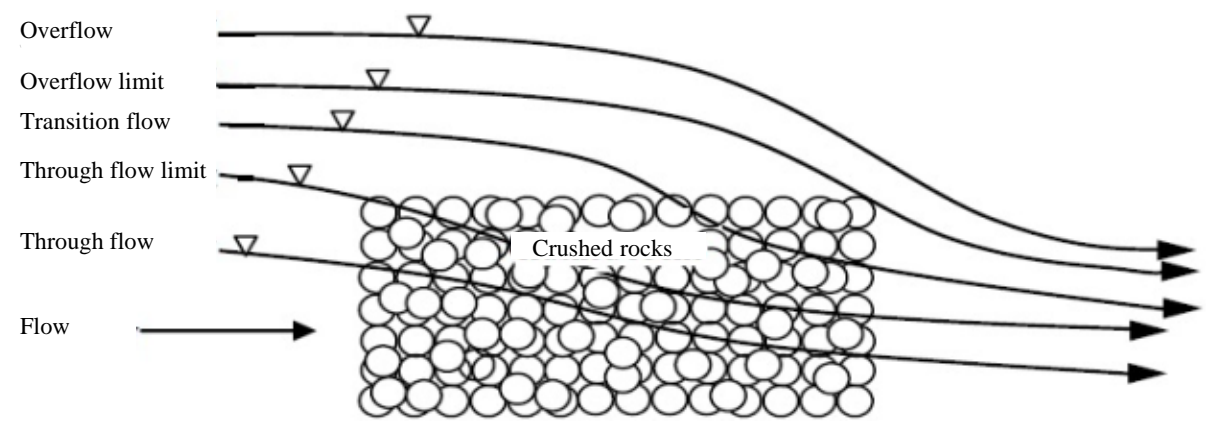

Fig. 2: Types of flow regimes for porous gabion 


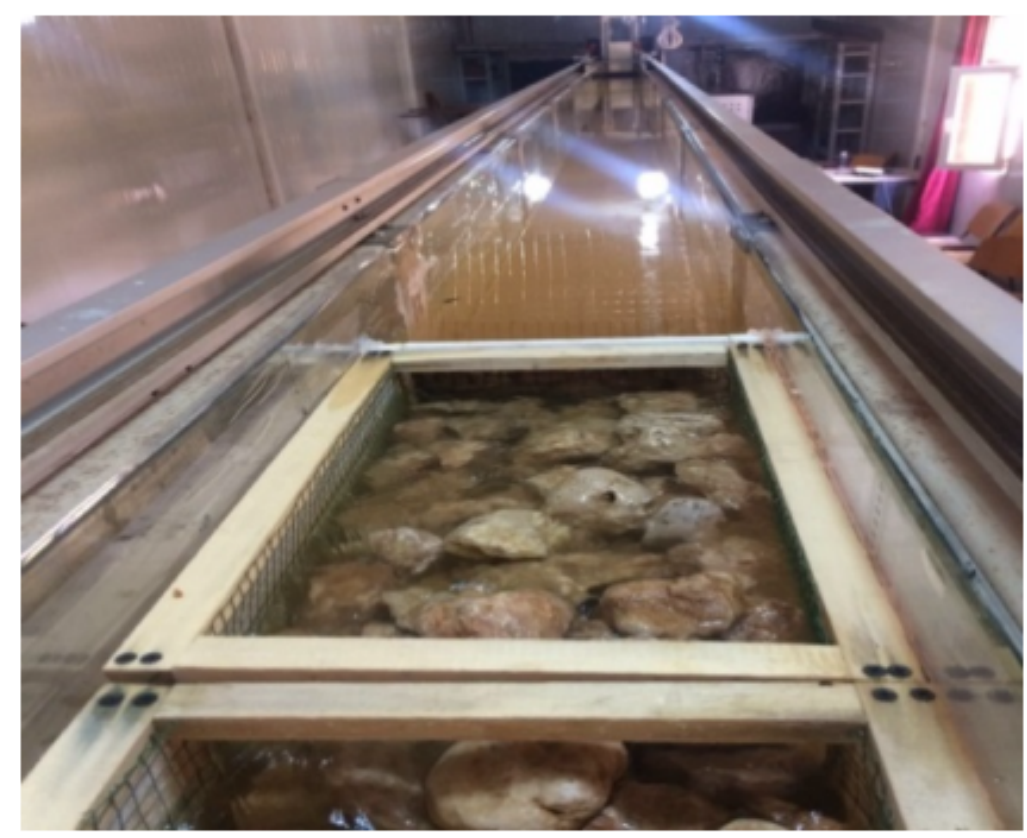

Fig. 3: General viewing of the laboratory flume

(a)

(b)

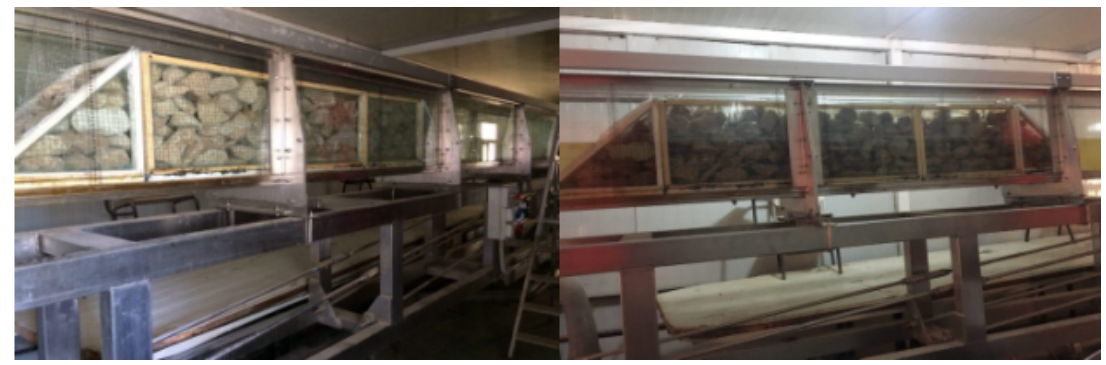

Fig. 4: Wooden gabion frame contain crushed rocks sample

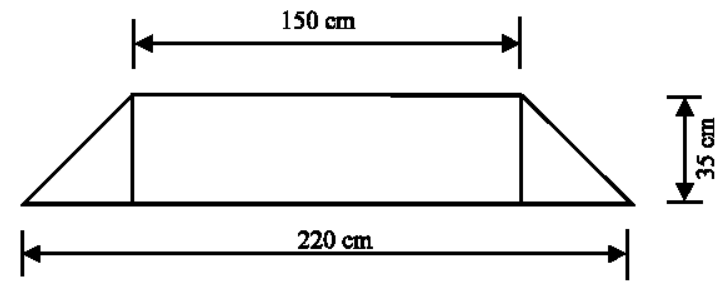

Fig. 5: Dimensions of wooden gabion, width $(30 \mathrm{~cm})$

Where:

$\mathrm{V}_{\mathrm{v}}=$ The volume of voids $\left(\mathrm{m}^{3}\right)$

$V_{T}=$ The total volume of sample $\left(\mathrm{m}^{3}\right)$

In the current study, all the crushed rocks samples was tested in rectangular cross section and put in wooden frame meshed-side gabion with constant dimensions, $220 \mathrm{~cm}$ length of the bottom $150 \mathrm{~cm}$ length of upper side of gabion, $0.3 \mathrm{~m}$ width and $0.35 \mathrm{~mm}$ height (Fig. 4 and 5).
Table 1: The general characteristics of the three rocky porous media models Monosized sample $\mathrm{d}_{5 n}(\mathrm{~mm}) \quad$ Density of particle $\left(\mathrm{g} / \mathrm{cm}^{3}\right)$ Porosity (\%)

\begin{tabular}{llll}
\hline$(-76,+64)$ & 71.5 & 3.04 & 49.71 \\
$(-64,+50)$ & 59.3 & 2.96 & 47.57
\end{tabular}

\begin{tabular}{llll}
$(-50,+37.5)$ & 42.3 & 2.87 & 44.26 \\
\hline
\end{tabular}

Table 2: The general characteristics of the three rocky porous media models

\begin{tabular}{|c|c|c|c|c|c|}
\hline \multirow[b]{2}{*}{ Parameters } & \multirow[b]{2}{*}{ Symbol } & \multirow[b]{2}{*}{ Value } & \multicolumn{2}{|l|}{ Range } & \multirow[b]{2}{*}{ Units } \\
\hline & & & From & To & \\
\hline Rock size & $\mathrm{d}_{50}$ & Different & 42.3 & 71.5 & $\mathrm{~mm}$ \\
\hline $\begin{array}{l}\text { Hydraulic gradient } \\
\text { length }\end{array}$ & $\mathrm{L}$ & 200 & --- & --- & $\mathrm{cm}$ \\
\hline Height of gabion & $\mathrm{H}$ & 35 & --- & --- & $\mathrm{cm}$ \\
\hline Width of gabion & $\mathrm{w}$ & 30 & --- & --- & $\mathrm{cm}$ \\
\hline $\begin{array}{l}\text { Longitudinal } \\
\text { slope }\end{array}$ & $\mathrm{s}$ & Different & 0 & 0.028 & --- \\
\hline Discharge & $\mathrm{O}$ & Different & $5.41 \mathrm{E}-06$ & 0.004257 & $\mathrm{~m}^{3} / \mathrm{sec}$ \\
\hline
\end{tabular}

All experimental laboratory conditions were summarized in the Table 1 and 2 , taking into consideration that all experiments were conducted under through flow condition, total number of runs were 92 . 
Steps for conducting laboratory experiments according to the conditions in Table 2 and Fig. 5 were listed:

Step 1; A wooden frame gabion was manufactured with glass-sided supported by wire mesh to protect the glass-sided of laboratory flume from sided pressure of rock fill

Step 2; Putting the wooden gabion frame inside the laboratory flume, then the first crushed rocks sample $(-76,+64)$ put inside the gabion as porous medium

Step 3; Install the longitudinal slope of the channel in horizontal mode

Step 4; Setting up the discharge by altering a control valve in the flume-equipping pipe

Step 5; Expectation in order to reach the balance in depth of flow rate

Step 6; Measuring the discharge, upstream water depth, downstream water depth and velocity at the downstream side of gabion

Step 7; Changing the discharge value as in step 4

Step 8; The steps 5-7 was repeating 10 times

Step 9; The steps 2-8 was repeating for other crushed rock monosize $((-64,50),(-50,+37.5) \mathrm{mm}$ and other longitudinal slopes $(0.014,0.028)$

Dimensional analysis: Through the use of dimensional analysis of the variables affecting the velocity of the flow after the gabion thus can be expressed as functional forms (Omran et al., 2016):

$$
v_{\text {down }}=f\left(Q, S, h_{1}, h_{2}, \rho, g, d_{50}\right)
$$

Where:

$$
\begin{array}{ll}
v_{\text {downstream }}= & \text { Velocity of flow at downstream side beyond } \\
& \text { the gabion } \\
\mathrm{Q} & =\text { Flow rate } \\
\mathrm{S} & =\text { Longitudinal Slope of flume } \\
\mathrm{h}_{1} & =\text { Head of water at upstream } \\
\mathrm{h}_{2} & =\text { Head of water at downstream } \\
\rho & =\text { Mass of density for water } \\
\mathrm{g} & =\text { Gravitational acceleration } \\
\mathrm{d}_{50} & =\text { Particle size }
\end{array}
$$

$$
\mathrm{f}\left(v_{\text {down }}, \mathrm{Q}, \mathrm{S}, \mathrm{h}_{1}, \mathrm{~h}_{2}, \rho, \mathrm{g}, \mathrm{d}_{50}\right)=0
$$

$\pi$ theory by Buckingham was used to drive a dimensionless formula in which $\rho, g$ and $d_{50}$ were chose as repeated variable :

$$
\frac{v_{\text {downstream }}}{\sqrt{\mathrm{g}^{*} \mathrm{~d}_{50}}}=\mathrm{f}\left(\frac{\mathrm{Q}}{\sqrt{\mathrm{g}^{*} \mathrm{~d}_{50}^{5}}}, \mathrm{~S}, \frac{\mathrm{h}_{1}}{\mathrm{~d}_{50}}, \frac{\mathrm{h}_{2}}{\mathrm{~d}_{50}}\right)
$$

\section{RESULTS AND DISCUSSION}

The current paragraph depicts the analysis of results from the experimental investigation, Fig. 6 illustrates the relation between the velocity at downstream of flow $\left(v_{\mathrm{DSS}}\right)$ at behind the gabion and the discharge $(\mathrm{Q})$ that passes through the gabion under effects of longitudinal slope of flume with same size of fill material, it is clear that the relation between $v_{D . S}$ and $Q$ is still linear and there is no significant effects for same filling size with different values of longitudinal slope.

From regression with a linear relation was carried out to valuation $v_{D . S}$ values. Table 3 shows under different cases the formulas for valuation $v_{D . S}$.
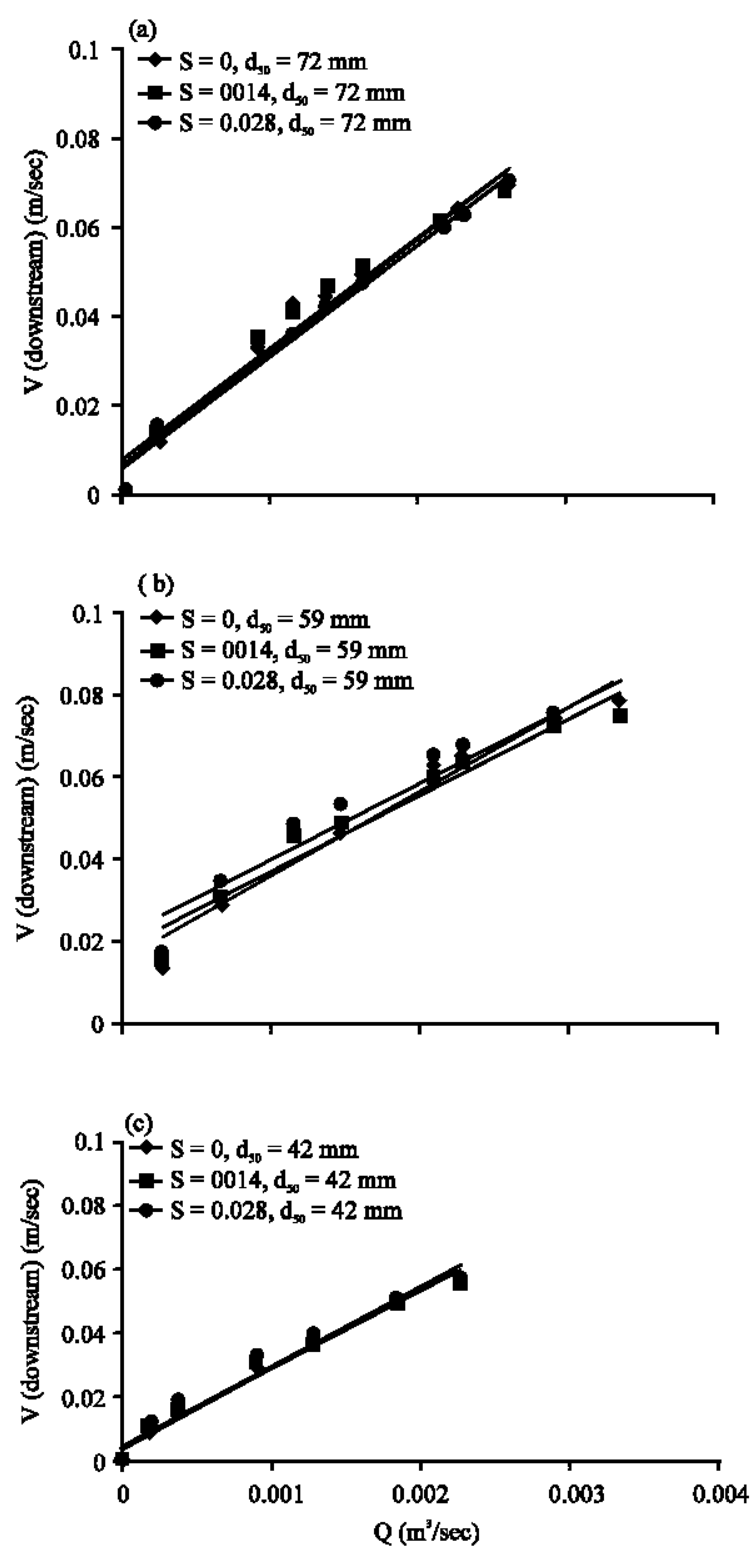

Fig. 6: a-c) Observed values of downstream velocity 
Table 3: Formulas for valuation

\begin{tabular}{lllc}
\hline $\mathrm{d}_{50}(\mathrm{~mm})$ & $\mathrm{S}$ & $v_{D . S}$ formula & $\mathrm{R}^{2}$ \\
\hline 72 & 0 & $v_{D . S}=26.32 \mathrm{Q}+0.0066$ & 0.975 \\
72 & 0.014 & $v_{D . S}=26.209 \mathrm{Q}+0.0053$ & 0.989 \\
72 & 0.028 & $v_{D . S}=25.857 \mathrm{Q}+0.0076$ & 0.967 \\
59 & 0 & $v_{D . S}=25.844 \mathrm{Q}+0.0035$ & 0.982 \\
59 & 0.014 & $v_{D . S}=25.628 \mathrm{Q}+0.0045$ & 0.975 \\
59 & 0.028 & $v_{D . S}=25.372 \mathrm{Q}+0.0039$ & 0.979 \\
42 & 0 & $v_{D . S}=20.637 \mathrm{Q}+0.0161$ & 0.957 \\
42 & 0.014 & $v_{D . S}=19.074 \mathrm{Q}+0.0185$ & 0.953 \\
42 & 0.028 & $v_{D S}=18.924 \mathrm{Q}+0.0218$ & 0.916 \\
\hline
\end{tabular}

Table 4: Comparison between the observed and calculated velocity at downstream.

\begin{tabular}{lcc}
\hline$v_{D S}$ (observed) & $v_{D S}$ (calculated) & Difference $(\%)$ \\
\hline 0.06441 & 0.06322 & 1.88234 \\
0.07138 & 0.06993 & 2.07045 \\
0.07506 & 0.07656 & 1.96822 \\
0.06796 & 0.06920 & 1.80087 \\
0.07096 & 0.06901 & 2.82110 \\
0.08023 & 0.07621 & 5.27584 \\
0.08369 & 0.07906 & 5.85069 \\
0.08694 & 0.08881 & 2.10838 \\
0.08223 & 0.07793 & 5.51522 \\
0.09039 & 0.08850 & 2.14080 \\
\hline
\end{tabular}

The comparison between the formulas in Table 3 shows that the effect of $Q$ on $v_{D . S}$ decreases by decreasing of gravel size and the effect of $Q$ on $v_{D . S}$ decrease by increasing the longitudinal slope, all comparison doing under the same geometric dimension of gabion.

A non-linear regression analysis by using IBM SPSS 21 program to estimate the correlation between the different dimensionless parameters mention in Eq. 1 and evolves the formula to estimate the downstream velocity in throughflow regime, the correlation coefficient $\mathrm{R}^{2}$ for the development equation is 0.963 and its expression:

$$
\begin{aligned}
& \frac{\mathrm{v}_{\text {D.S }}}{\sqrt{\mathrm{g}^{*} \mathrm{~d}_{50}}}=\left[0.143 *\left(\frac{\mathrm{Q}}{\sqrt{\mathrm{g} * \mathrm{~d}_{50}^{5}}}\right)^{0.79}\right]- \\
& {\left[405.107 *(\mathrm{~S})^{3.505}\right]+\left[0.006^{*}\left(\frac{\mathrm{h}_{1}}{\mathrm{~d}_{50}}\right)^{0.658}\right]-} \\
& {\left[0.008^{*}\left(\frac{\mathrm{h}_{2}}{\mathrm{~d}_{50}}\right)^{2.792}\right]}
\end{aligned}
$$

A comparison between the observed values and calculated from the regression Eq. 4 for velocity at downstream was listed in Table 4 as follows.

Figure 7 show a good agreement for the values of $v_{D . S}$ were calculated from Eq. 4 plotted versus the values of $v_{D . S}$ observed from the laboratory test.

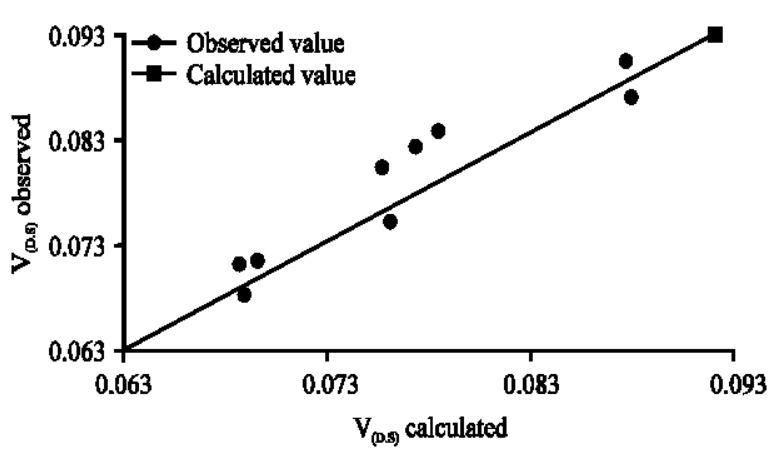

Fig. 7: Observed values of velocity at downstream versus calculated values

\section{CONCLUSION}

In the current study, many laboratory tests carried out to investigate the velocity at downstream side closely after pass the flow through the gabion, the following conclusion were found according to the results: the relation between the discharge value and the velocity at downstream was linear for all gravel size and longitudinal slope. The effect of discharge increase on the velocity at downstream when the rockfill size increase. The effect of discharge decrease on the velocity at downstream when the longitudinal slope increase. By using ( $\pi$-theory) method as dimensional analysis concept, non-linear regression analysis by using IBM SPSS 21 program an empirical equation developed for computed the velocity at downstream.

\section{REFERENCES}

Al-Mohammed, F.M. and S.H. Mohammed, 2015. Flow through and over gravel gabion weirs. J. Kerbala Univ., 13: 193-205.

Izbash, S.V., 1970. Hydraulics of River Channel Closure. Butterworths, London, UK., Pages: 174.

Leps, T.M., 1973. Flow through Rockfill. In: Embankment dam Engineering: Casagrande Volume, Hirschfeld, R.C. and S.J. Polous (Eds.). John Wiley and Sons, Hoboken, New Jersey, USA., pp: 86-1 07.

Maeno, S., K. Michioku, S. Morinaga and T. Ohnishi, 2002. Hydraulic characteristics of a rubble mound weir and its failure process. Proceedings of the 5th International Conference on Hydroscience and Engineering (ICHE'02), September 18-21, 2002, Warsaw University of Technology, Warsaw, Poland, pp: 1-7. 
Omran, H.A., S.I. Khassaf and F.A. Hassan, 2016. The effect of flow conditions and geometric parameters on the scour value downstream composite structures of weir and gate. Kufa J. Eng., 7: 115-128.

Parkin, A.K., 1963. Rockfill Dams with Inbuilt Spillways: Part I-Hydraulic Characteristics. Water Research Foundation of Australia, Australia,.
Shekho, A.A., 2009. Determaination of the coefficient of transmissibility of quarried rocks. J. Al Taqani, 22: A64-A73.

Terzaghi, K., R.B. Peck and G. Mesri, 1996. Soil Mechanics in Engineering Practice. 3rd Edn., John Wiley and Sons, Inc, New York, USA., ISBN-13: 9780471086581 , Pages: 549 